\title{
BTK Inhibitor
}

National Cancer Institute

\section{Source}

National Cancer Institute. BTK Inhibitor. NCI Thesaurus. Code C124801.

Any drug or substance that inhibits the activity of tyrosine-protein kinase BTK protein. 